\title{
Ocena linii wsobnych kapusty głowiastej białej pod względem przydatności do hodowli odpornościowej na stres suszy
}

\author{
Evaluation of the cabbage inbreed lines for resistance breeding to drought stress
}

\author{
Piotr Kamiński ${ }^{1 \oplus}$, Waldemar Treder ${ }^{2 \oplus}$, Krzysztof Klamkowski $^{2 \oplus}$
}

\author{
${ }^{1}$ Pracownia Genetyki i Hodowli Roślin Warzywnych, Zakład Hodowli Roślin Ogrodniczych, Instytut \\ Ogrodnictwa - Państwowy Instytut Badawczy, ul. Konstytucji 3 Maja 1/3, 96-100 Skierniewice, \\ 2Zakład Agroinżynierii, Pracownia Nawadniania, Instytut Ogrodnictwa - Państwowy Instytut Badawczy, \\ ul. Konstytucji 3 Maja 1/3, 96-100 Skierniewice, \\ $\triangle$ e-mail: piotr.kaminski@inhort.pl
}

\begin{abstract}
Dwanaście linii wsobnych kapusty głowiastej białej otrzymanych w Pracowni Genetyki i Hodowli Roślin Warzywnych, Zakład Hodowli Roślin Ogrodniczych Instytutu Ogrodnictwa - PIB zostało poddanych ocenie pod względem cech morfologicznych, dynamice wzrostu systemu korzeniowego, intensywności fotosyntezy oraz transpiracji, które mogą wpływać na ich odporność na stres suszy. Badania prowadzono w warunkach kontrolowanych w fazie wiązania główek jak również w fazie dojrzałości zbiorczej na polu doświadczalnym. Wszystkie linie wsobne odznaczały się wysoką wartością hodowlaną oraz wyrównaniem, były również silnie zróżnicowane pod względem badanych cech. Linie wsobne kapusty różniły się pod względem reakcji na stres suszy. Genotypy o dużej dynamice wzrostu systemu korzeniowego, mniejszych liściach oraz kompaktowym pokroju roślin, które odznaczały się silniejszym ograniczeniem fotosyntezy oraz transpiracji w warunkach stresu suszy, mogą być wykorzystywane do hodowli odpornościowej. Wysoki poziom zróżnicowania linii wsobnych umożliwia uzyskanie efektu heterozji przy tworzeniu nowych eksperymentalnych mieszańców $F_{1}$ lepiej przystosowanych do niekorzystnych warunków środowiska w tym na stres niedoboru wody.
\end{abstract}

\begin{abstract}
Słowa kluczowe: cechy morfologiczne i użytkowe, fotosynteza, hodowla, kapusta głowiasta, linie wsobne, stres suszy, transpiracja

Twelve head cabbage inbred lines obtained at the Research Institute of Horticulture, Department of Genetics and Breeding, Skierniewice, Poland were evaluated in respect to the morphological characters, dynamic of the root development, photosynthesis and transpiration activity that could affect their resistance for the drought stress. The evaluation was conducted in controlled conditions at head formation stage and at the field when cabbage reached their maturity. All inbred lines were uniform with high breeding value but they were also highly diversified in respect to their characters. Different reactions for drought stress between the lines was recorded. Genotypes with high dynamics of root development, smaller leaf size, compact shape of plant, with stronger transpiration and photosynthesis reaction will be probably less susceptible to drought stress. High level of diversity of cabbage inbred lines reflects their potential for the breeding of the new $\mathrm{F}_{1}$ cultivars with better adaptation for the abiotic stresses including drought stress in the future.
\end{abstract}

Key words: morphological traits, photosynthesis, breeding, head cabbage, inbred lines, drought stress, transpiration

\section{Wstęp}

Kapusta głowiasta biała jest jednym z najważniejszych gatunków roślin warzywnych uprawianych w Polsce, której produkcja zajmuje około 23 tys. ha i wynosi ponad $1 \mathrm{mln}$ ton rocznie. Jest cennym źródłem witaminy $\mathrm{C}$, substancji prozdrowotnych i błonnika a dzięki kwaszeniu i przechowywaniu jest dostępna na rynku przez cały rok w stanie surowym i przetworzonym. Dużą rolę odgrywają odmiany mieszańcowe pochodzenia zagranicznego, które odznaczają się większym wyrównaniem, lepszym plonowaniem i zdrowotnością niż odmiany ustalone. Nowoczesna hodowla kapusty wymaga wykorzystania linii wsobnych o dobrej zdolności kojarzeniowej, wysokiej jakości, wyrównanych oraz odpornych na stresy biotyczne i abiotyczne (Dickson 2007) Hodowla mieszańców kapusty głowiastej białej jest prowadzona w Polsce w Pracowni Genetyki i Hodowli Roślin Warzywnych, Zakład Hodowli Roślin Ogrodniczych Instytutu Ogrodnictwa jak również $\mathrm{w}$ firmach hodowlano-nasiennych i ma duże znaczenie gospodarcze. Celem tych programów jest uzyskanie nowych mieszańców heterozyjnych mogących konkurować pod względem jakości, plonowania oraz odporności na stresy biotyczne i abiotyczne z odmianami zagranicznymi. Ze względu na zmiany klimatu i coraz 
powszechniejszy niedobór wody, jedną z najbardziej poszukiwanych cech jest wysoka odporność materiałów hodowlanych kapusty głowiastej białej na stres związany z suszą. Kapusta głowiasta biała jak i inne rośliny kapustowate jest gatunkiem o wysokich wymaganiach wodnych zarówno pod względem niedoboru jak i nadmiernej ilości wody, a stres związany $\mathrm{z}$ brakiem właściwego nawadniania uwidacznia się w postaci więdnięcia i zamierania liści, co w konsekwencji prowadzi do obniżenia lub całkowitej utraty plonu (Kaniszewski i Rumpel 1998, Wiebe 1981). Stres spowodowany deficytem wody prowadzi do szeregu fizjologicznych i biochemicznych zmian w organizmie roślinnym. W wyniku hamowania wymiany gazowej, a więc $\mathrm{i}$ asymilacji $\mathrm{CO}_{2}$, dochodzi do ograniczenia syntezy cukrów. Zmiana stosunków troficznych oraz dystrybucji substancji pokarmowych powoduje konieczność ograniczenia energochłonnych procesów wzrostu, a w skrajnych przypadkach nawet rozwoju generatywnego. Zahamowanie wzrostu, słabsze zawiązywanie owoców oraz obniżenie wielkości plonu a czasem również pogorszenie jego jakości było obserwowane podczas suszy u różnych gatunków roślin uprawnych (Boyer 1970; Singer $i$ in. 2003). Jedną $z$ pierwszych reakcji roślin na suszę jest zamykanie aparatów szparkowych. Powoduje to zmniejszenie transpiracji co jest jedną ze strategii chroniącą rośliny przed nadmierną utratą wody (Chaves i in. 2003). Zamykanie aparatów szparkowych prowadzi również do ograniczenia procesu pobierania dwutlenku węgla. Reakcję taką obserwowano u wielu gatunków roślin rosnących w warunkach niedoboru wody w podłożu (Chandler, Ferree 1990; Flore i in. 1985; Klamkowski, Treder 2006; Klamkowski i in., 2015). Faza wiązania główek jest jednym z najbardziej krytycznych momentów który decyduje o wysokości i jakości plonu kapusty (Smittle 1994). W tym okresie zapotrzebowanie na wodę i składniki odżywcze jest największe. W zależności od wczesności oraz cech morfologicznych, wiązanie główek następuje najczęściej po wytworzeniu 14-18 liści właściwych. Odmiany wczesne kapusty głowiastej, przeznaczone na zbiór 45-60 dni po posadzeniu na miejsce stałe, posiadają szczególnie wysokie wymaganiach wodno-pokarmowe i są bardziej podatne na stres wodny (Dickson 2007, Pavlović i in. 2019). Prowadzenie hodowli uwzględniającej odporności na stres związany z niedoborem wody jest procesem złożonym ze względu na kompleksowy mechanizm dziedziczenia kontrolowany przez ekspresję wielu genów o działaniu częściowym (Asharf i in. 2009, Giuseppe i Dichio, 2012) Hodowla odpornościowa roślin kapustowatych na stres suszy prowadzona jest zarówno w warunkach naturalnych jak również w warunkach kontrolowanych z wykorzystaniem biometrycznych metod uwzględniających wpływ czynników odpowiedzialnych za aktywność fotosyntezy oraz transpirację (Bahadur i in. 2011, Blum 1988). Poziom odporności kapusty głowiastej na stres wodny zależy również od cech morfologicznych i anatomicznych roślin takich jak powierzchnia, liczba, wielkość, struktura, unerwienie i grubość liści okrywających, pokrój roślin oraz intensywność nalotu woskowego oraz kształt i wielkość systemu korzeniowego (Leonardis i in 2012).

Celem podjętych badań była ocena dwunastu linii hodowlanych kapusty głowiastej białej: 1) w warunkach kontrolowanych w fazie wiązania główek pod względem dynamiki wzrostu systemu korzeniowego, cech morfologicznych związanych z odpornością na stres wodny oraz aktywności transpiracji i fotosyntezy w warunkach stresu suszy 2) w warunkach polowych (w okresie dojrzałości zbiorczej główek) pod względem masy, kształtu i wypełnienia główek, długości głąba wewnętrznego, długości okresu wegetacji a także pokroju roślin, unerwienia liści i nalotu woskowego.

\section{Material i Metody \\ Material}

Dwanaście linii hodowlanych kapusty głowiastej białej (PW1265, PW2517, PW1018, PW738, PW703, PW903, PW800, CW2517, PW910, PW1027, CW1018, CW738) zróżnicowanych pod względem pochodzenia oraz cech morfologicznych i użytkowych (Fot. 1A) wyselekcjonowano w Pracowni Genetyki i Hodowli Roślin Warzywnych Instytutu Ogrodnictwa PIB. Linie przeznaczone do oceny zostały wytworzone metodami hodowli wsobnej, odznaczały się wysokim poziomem homozygotyczności, wyrównaniem wewnątrzliniowym, dobrą zdolnością kojarzeniową oraz cechami typowymi dla form uprawnych w warunkach Polski.

\section{Warunki kontrolowane}

Linie wsobne kapusty głowiastej białej wysiano w trzecim tygodniu lutego do 2,5 1. doniczek wypełnionych mieszanką substratu torfowego (Kronen), piasku i perlitu (3:1:1) i uprawiano w szklarni temperaturze $16-20^{\circ} \mathrm{C}$ przy 12-godzinnym fotoperiodzie. Każda linia była reprezentowana przez 10 roślin. Nawadnianie i nawożenie prowadzono przy pomocy roztworu nawozu Kristalon Zielony $(0,3 \%)$ 18-18-18 + mikroelementy (Yara) przez uzupełnianie pożywki w matach podsiąkowych na których ustawiono doniczki. W celu obserwacji dynamiki 
wzrostu systemu korzeniowego w każdej z doniczek wycięto okno o wymiarach 9 x $13 \mathrm{~cm}$, które zabezpieczono przezroczystą, sztywną folią. (Fot. 1B). Okna odczytu na czas wegetacji zabezpieczono przed światłem z zewnątrz czarnym plastikiem. Rejestracja dynamiki wzrostu systemu korzeniowego prowadzona była dla trzech losowo wybranych roślin każdej $\mathrm{z}$ linii nawadnianej zgodnie z potrzebami. Obserwacje prowadzono od pierwszego tygodnia kwietnia, co siedem dni przez okres trzech tygodni. Rejestrację prowadzono poprzez ręczne odwzorowanie przy pomocy markera liczby i długości wszystkich korzeni widocznych w oknie odczytu. Odwzorowanie wykonano na przezroczystej folii wykorzystując 3 różne kolory dla dorysowania kolejnych nowo wytworzonych korzeni które wyrosły w danym terminie pomiaru. (Fot. 1C). Uzyskane zarysy odwzorowania systemu korzeniowego zostały zeskanowane i poddane analizie komputerowej pozwalającej na określenie przyrostu długości korzeni w 1, 2 i 3 tygodniu obserwacji.

Ocenę cech morfologicznych W zależności od stresu wodnego oraz natężenia fotosyntezy i transpiracji przeprowadzono w fazie 16 liści właściwych, w czwartym tygodniu kwietnia. Dla 3 losowo wybranych roślin każdej z linii dokonano pomiarów średnicy łodygi przy szyjce korzeniowej (mm), średniej masy części nadziemnej (g) i średniej wysokości roślin (cm). Pozostałe cechy takie jak barwa, unerwienie liścia oraz nalot woskowy zostały ocenione według kilkustopniowej umownej skali bonitacyjnej zgodnie z UPOV (International Union for the Protection of New Varieties of Plants). W celu oceny stresu suszy, dla pięciu roślin każdej z linii kapusty głowiastej, zaprzestano nawadniania, pozostałe rośliny każdej z linii stanowiły grupę kontrolną. Reakcję na stres spowodowany suszą oceniono po upływie 72 godzin dokonując pomiarów natężenia fotosyntezy oraz transpiracji przy wykorzystaniu analizatora $\mathrm{LCPro}^{+}, \mathrm{ADC}$ BioScientific, UK oraz oceny stopnia zwiędnięcia roślin w 10-stopniowej skali zarówno dla grupy roślin poddanych stresowi jak i grupy kontrolnej.

\section{Ocena w warunkach polowych}

Dwanaście linii wsobnych kapusty głowiastej białej oceniono $\mathrm{w}$ doświadczeniu porównawczym na polu doświadczalnym Instytutu Ogrodnictwa - PIB w Skierniewicach. Rośliny w fazie rozsady wysadzono $\mathrm{w}$ trzecim tygodniu maja $\mathrm{w}$ rozstawie 50 x $60 \mathrm{~cm}$ na miejsce stałe w układzie bloków losowanych $\mathrm{w}$ trzech powtórzeniach po 20 roślin w każdym powtórzeniu. W celu zapewnienia ochrony przed chorobami i szkodnikami oraz dla prawidłowego wzrostu roślin zastosowano właściwą dla tego gatunku ochronę chemiczną oraz nawożenie. W trakcie wegetacji nie stosowano dodatkowego nawadniania, zachowując naturalne warunki sprzyjające wystąpieniu stresu suszy, która wystąpiła na przełomie czerwca i lipca po 2 tygodniowym braku opadów oraz wysokim nasłonecznieniu (pomiary średniej sumy i częstotliwości opadów oraz temperatury dla Skierniewic, stacja meteorologiczna IO). Oceny stopnia zwiędnięcia roślin dokonano w czwartym tygodniu czerwca w 10-stopniowej skali bonitacyjnej gdzie 10 stanowiło brak objawów a 1 całkowite uschnięcie. Oceny cech morfologicznych i użytkowych dokonano $\mathrm{w}$ fazie dojrzałości zbiorczej główek indywidualnie dla każdej z linii. Dokonano pomiarów masy (kg) i kształtu główek (stosunek wysokości do szerokości główki), procentowego udziału głąba wewnętrznego w główce (stosunek długości głąba wewnętrznego do wysokości główki) oraz długości okresu wegetacji od sadzenia do osiągnięcia dojrzałości zbiorczej. Pozostałe cechy takie jak pokrój roślin, unerwienie liści, nalot woskowy, barwa liści zewnętrznych, osadzenie główek, barwa miąższu oraz wypełnienie główek badano na podstawie kilkustopniowej skali bonitacyjnej według UPOV.

\section{Analiza statystyczna}

Przyrost długości korzeni w poszczególnych okresach oceny w fazie 16 liści właściwych: średnica szyjki korzeniowej, średnia masa części nadziemnej, średnia wysokość roślin, w fazie dojrzałości zbiorczej: średnia masa główek, kształt główek oraz długość głąba wewnętrznego były poddane jednoczynnikowej analizie wariancji przy wykorzystaniu testu Newmana-Keulsa na poziomie istotności $\mathrm{P}=0,05$ (program STATISTICA package StatSoft v.10).

\section{Wyniki \\ Warunki kontrolowane}

Porównanie wyników przyrostu długości korzeni w kolejnych terminach dla każdej z linii wsobnych pozwoliło na wyliczenie całkowitej długości korzeni jak również dynamiki przyrostu długości korzenia w poszczególnych fazach rozwoju roślin. Linie wsobne kapusty głowiastej białej różniły się między sobą pod względem dynamiki wzrostu systemu korzeniowego (Tabela 1). Linie PW1018 i CW1018 odznaczały się większą dynamiką wzrostu systemu korzeniowego w pierwszym terminie obserwacji (46 dni od wysiewu) (odpowiednio 13,6 i 11,9 cm) podczas gdy linie PW910, PW903 i CW738 wykazywały w tym terminie najsłabszy 
przyrost (odpowiednio 0,9, 1,2, 1,62 cm). W drugim terminie obserwacji (53 dni od wysiewu) największe przyrosty długości korzeni zostały zaobserwowane dla linii PW1027 (113,2 cm), PW800 $(102,5 \mathrm{~cm})$ i linii CW2517 $(98,8 \mathrm{~cm})$, natomiast linie CW1018, PW910 i PW903 miały najsłabsze przyrosty (odpowiednio 43,2, 50,4 i 53,1 cm). Średnia dynamika przyrostu systemu korzeniowego dla wszystkich badanych linii kapusty głowiastej białej w 3 terminie obserwacji $(113,7 \mathrm{~cm})$ była większa niż w drugim $(72,5 \mathrm{~cm})$ i pierwszym terminie $(5,7 \mathrm{~cm})$.
Podobnie jak w drugim terminie linie PW1027 i PW800 charakteryzowały się największym przyrostem systemu korzeniowego $\mathrm{w}$ trzecim terminie obserwacji (odpowiednio 144,2 i 141,3 cm). Liniami o najdłuższym systemie korzeniowym na podstawie sumarycznej oceny ich długości po 60 dniach od wysiewu były PW1017 $(259,5 \mathrm{~cm})$ i PW800 (249,8 cm), najsłabszym wzrostem systemu korzeniowego odznaczały się linie CW1018 (135,6 cm), PW703 $(140,4 \mathrm{~cm})$ i PW903 $(146,4 \mathrm{~cm})$ (Tabela 1).

Tabela 1

Table 1

Przyrost długości korzeni (cm) linii wsobnych kapusty głowiastej białej w trzech terminach pomiarów, warunki kontrolowane.

Dynamics of the roots development $(\mathrm{cm})$ of head cabbage inbred lines at three terms of measure, controlled conditions.

\begin{tabular}{|c|c|c|c|c|}
\hline $\begin{array}{l}\text { Linia } \\
\text { Line }\end{array}$ & $\begin{array}{l}\text { Termin I ( } 48 \text { dni od wysiewu) } \\
\text { Term I (48 days after sowing) }\end{array}$ & $\begin{array}{l}\text { Termin II ( } 53 \text { dni od wysiewu) } \\
\text { Term II (53 days after sowing) }\end{array}$ & $\begin{array}{l}\text { Termin III ( } 60 \text { dni od wysiewu) } \\
\text { Term III ( } 60 \text { days after sowing) }\end{array}$ & $\begin{array}{l}\text { Suma I-III termin } \\
\text { Total I-III terms }\end{array}$ \\
\hline PW1265 & $2,32 \mathrm{ab}$ & 79,16 abcd & 115,12 bcde & 196,6 bc \\
\hline PW2517 & $8,16 \mathrm{abc}$ & $90,42 \mathrm{bcd}$ & $121,80 \mathrm{cde}$ & $220,38 \mathrm{c}$ \\
\hline PW1018 & $13,64 \mathrm{c}$ & $59,28 \mathrm{abc}$ & $88,73 \mathrm{abc}$ & $161,65 \mathrm{ab}$ \\
\hline PW738 & $8,36 \mathrm{abc}$ & $59,44 \mathrm{abc}$ & $103,38 \mathrm{abc}$ & $171,18 \mathrm{ab}$ \\
\hline PW703 & $8,46 a b c$ & $58,18 \mathrm{abc}$ & $73,78 \mathrm{a}$ & $140,42 \mathrm{a}$ \\
\hline PW903 & $1,24 \mathrm{a}$ & $53,10 a b$ & $92,10 \mathrm{abc}$ & $146,44 \mathrm{a}$ \\
\hline PW800 & $6,92 \mathrm{abc}$ & $101,52 \mathrm{~cd}$ & $141,32 \mathrm{de}$ & $249,76 \mathrm{~d}$ \\
\hline CW2517 & $2,68 \mathrm{ab}$ & $98,78 \mathrm{~cd}$ & $109,88 \mathrm{bcd}$ & $211,34 \mathrm{c}$ \\
\hline PW910 & 0,9 a & $50,4 \mathrm{ab}$ & $104,26 \mathrm{abc}$ & $155,56 \mathrm{ab}$ \\
\hline PW1027 & $2,08 \mathrm{ab}$ & $113,20 \mathrm{~d}$ & $144,22 \mathrm{e}$ & $259,5 \mathrm{~d}$ \\
\hline CW1018 & $11,92 \mathrm{bc}$ & $43,20 \mathrm{a}$ & $83,52 \mathrm{ab}$ & $138,64 \mathrm{a}$ \\
\hline CW738 & $1,62 \mathrm{a}$ & $60,30 \mathrm{abc}$ & $97,22 \mathrm{abc}$ & $159,14 \mathrm{ab}$ \\
\hline Średnia & 5,69 & 72,25 & 113,75 & 184,22 \\
\hline
\end{tabular}

Linie wsobne kapusty głowiastej białej uprawiane $\mathrm{w}$ fazie 16 liści właściwych uprawiane w warunkach szklarniowych charakteryzowały się zróżnicowanymi cechami morfologicznymi takimi jak średnica szyjki korzeniowej, średnia masa części nadziemnej, średnia wysokość roślin, unerwienie, nalot woskowy brzeg i barwa liścia (Tabela 2). Najszerszą szyjką korzeniową odznaczały się linie CW2517, PW800 i PW903 (odpowiednio 12,3, 12,2, 11,8 mm), najwęższą linia PW1265 $(7,5 \mathrm{~mm})$. Średnia masa części nadziemnej ważona bezpośrednio po ścięciu wynosiła od $215 \mathrm{~g}$. (linia PW1265) do 292 g. (linia PW903). Średnia wysokość roślin dla linii CW1018 i PW800 (19.8, $20.2 \mathrm{~cm}$ ) była istotnie niższa niż dla linii późnych PW2517 i CW2517 (odpowiednio 25.6 i $25.3 \mathrm{~cm}$ ).
Liniami o najintensywniejszym unerwieniu były PW738 i CW738, natomiast najsłabsze unerwienie liści posiadały linie PW800 i PW1018. Cztery spośród dwunastu genotypów wytwarzało silny wosk (PW1265, PW2517, PW738 i PW1027), jedynie dwie linie PW1018 i CW1018 posiadały słaby nalot woskowy na powierzchni liści. Linie PW1265, CW2517 i PW1027 odznaczały się karbowanym brzegiem liścia, podczas gdy pozostałe były gładkie lub faliste. Większość linii odznaczała się zieloną barwą liści, cztery linie były ciemnozielone (PW2517, PW738, PW1027, CW1018) (Tabela 2). Reakcja poszczególnych genotypów na stres suszy w warunkach kontrolowanych była zróżnicowana od stosunkowo silnej, powodującej zamieranie starszych liści i częściowe więdnięcie całych roślin 
(PW703, PW903 i PW910) do niewielkiej w posta- (PW2517, CW1018, PW738, CW2517) (Tabela 2,

ci częściowego więdnięcia liści zewnętrznych Fot. 1D, 1E, 1F, 1G).

Tabela 2

Table 2

Cechy morfologiczne linii wsobnych kapusty głowiastej białej w fazie 16 liści właściwych w warunkach kontrolowanych. Morphological characters of head cabbage inbred lines at $\mathbf{1 6}$ leaf stage in controlled conditions.

\begin{tabular}{|c|c|c|c|c|c|c|c|c|}
\hline $\begin{array}{l}\text { Linia } \\
\text { Line }\end{array}$ & $\begin{array}{c}\text { Szyjka } \\
\text { korzeniowa } \\
(\mathrm{mm}) \\
\text { Root collar } \\
(\mathrm{mm})\end{array}$ & $\begin{array}{c}\text { Średnia masa cz. } \\
\text { nadziemnej (g) } \\
\text { Avg. mass of } \\
\text { aerial part (g) }\end{array}$ & $\begin{array}{c}\text { Średnia } \\
\text { wysokość roślin } \\
\text { (cm) } \\
\text { Avg. height } \\
\text { of plants }\end{array}$ & $\begin{array}{l}\text { Unerwienie } \\
\text { liści } \\
\text { Leaf innerva- } \\
\text { tion }\end{array}$ & $\begin{array}{c}\text { Nalot } \\
\text { woskowy } \\
\text { Waxiness }\end{array}$ & $\begin{array}{c}\text { Brzeg liścia } \\
\text { Leaf edge }\end{array}$ & $\begin{array}{l}\text { Barwa liścia } \\
\text { Leaf color }\end{array}$ & $\begin{array}{l}\text { Stres suszy } \\
\text { Drought } \\
\text { stress }\end{array}$ \\
\hline PW1265 & $7,5 \mathrm{a}$ & $215 \mathrm{a}$ & $24,3 \mathrm{~cd}$ & 2 & 3 & 3 & 2 & 7 \\
\hline PW2517 & $9,8 \mathrm{ab}$ & $237 \mathrm{ab}$ & $25,3 \mathrm{~d}$ & 2 & 3 & 1 & 3 & 9 \\
\hline PW1018 & $9,8 \mathrm{ab}$ & $220 \mathrm{a}$ & $22,3 \mathrm{ac}$ & 1 & 1 & 1 & 2 & 7 \\
\hline PW738 & $10,2 \mathrm{ab}$ & $242 \mathrm{ab}$ & $22,3 \mathrm{ac}$ & 3 & 3 & 1 & 3 & 9 \\
\hline PW703 & $10,9 \mathrm{ab}$ & $276 a b$ & $22,0 \mathrm{ac}$ & 2 & 2 & 1 & 2 & 6 \\
\hline PW903 & $11,8 \mathrm{~b}$ & 292 b & $20,5 \mathrm{ab}$ & 2 & 2 & 2 & 2 & 5 \\
\hline PW800 & $12,2 \mathrm{~b}$ & $220 \mathrm{a}$ & $20,2 \mathrm{a}$ & 1 & 2 & 1 & 2 & 7 \\
\hline CW2517 & $12,3 b$ & $259 \mathrm{ab}$ & $25,6 \mathrm{~d}$ & 2 & 2 & 3 & 2 & 9 \\
\hline PW910 & $11,1 \mathrm{ab}$ & $282 a b$ & 23,0 ad & 2 & 2 & 1 & 2 & 6 \\
\hline PW1027 & $10,4 \mathrm{ab}$ & $275 a b$ & $20,7 \mathrm{ab}$ & 2 & 3 & 3 & 3 & 6 \\
\hline CW1018 & $8,9 \mathrm{ab}$ & $267 \mathrm{ab}$ & $19,8 \mathrm{a}$ & 2 & 1 & 0 & 3 & 9 \\
\hline CW738 & $10,6 \mathrm{ab}$ & $260 \mathrm{ab}$ & $23,4 \mathrm{bd}$ & 3 & 2 & 2 & 2 & 7 \\
\hline $\begin{array}{l}\text { Unerwienie } \\
\text { Nalot wosko } \\
\text { Brzeg liścia } \\
\text { Barwa liścic } \\
\text { Stres suszy: }\end{array}$ & & $\begin{array}{l}1 \text { - słabe, } \\
0-\text { brak, } \\
0 \text { - gładki, } \\
1 \text { - jasnozielona, } \\
1 \text { - catkowite zasch }\end{array}$ & $\begin{array}{l}2 \text {-średnie, } \\
1 \text { - staby, } \\
1 \text { - lekko falisty, } \\
2 \text { - zielona, } \\
\text { ilęcie, }\end{array}$ & $\begin{array}{l}\text { 3-silne } \\
\text { 2- sredni, } \\
2 \text { - falisty, } \\
3 \text { - ciemnoziel } \\
10 \text { - brak obja }\end{array}$ & \multicolumn{2}{|c|}{$\begin{array}{l}3-\text { silny } \\
3-\text { karbowany } \\
\text { ná } \\
\text { wów }\end{array}$} & & \\
\hline $\begin{array}{l}\text { Leaf innerve } \\
\text { Waxiness: } \\
\text { Edge of leaf } \\
\text { Leaf color: } \\
\text { Drought str }\end{array}$ & & $\begin{array}{l}1 \text { - weak, } \\
0-\text { absence, } \\
0-\text { entire, } \\
1 \text { - light green, } \\
1 \text { - total death, }\end{array}$ & $\begin{array}{l}2 \text { - medium, } \\
1 \text { - weak, } \\
1 \text { - crenate, } \\
2 \text { - green, } \\
10-\text { no symptoms }\end{array}$ & $\begin{array}{l}3 \text { - strong } \\
2 \text { - medium, } \\
2 \text { - dentate, } \\
3 \text { - dark green }\end{array}$ & \multicolumn{2}{|l|}{$\begin{array}{l}3 \text { - strong } \\
3 \text { - serrate }\end{array}$} & & \\
\hline
\end{tabular}

Ocena intensywności wymiany gazowej liści dla badanych linii kapusty głowiastej w warunkach kontrolnych i stresu suszy wykazała wysoki poziom zróżnicowania. Natężenie fotosyntezy było zróżnicowane zarówno wśród linii w warunkach optymalnego podlewania jak i poddanych stresowi suszy (Rys. 1). Najwyższym natężeniem fotosyntezy w warunkach optymalnych odznaczały się linie CW1018, PW903, PW738, PW703 i PW1265 (25-23 $\mu \mathrm{mol} \mathrm{CO} \mathrm{m}^{-2} \mathrm{~s}^{-1}$ ), najniższym linie CW738 i PW800 (odpowiednio 18,5 i $19 \mu \mathrm{mol} \mathrm{CO}_{2} \mathrm{~m}^{-2} \mathrm{~s}^{-1}$ ). Stres suszy obniżył natężenie fotosyntezy u większości badanych obiektów z wyjątkiem linii PW2517, a reakcja linii wsobnych była zróżnicowana. Linia PW903 odnotowała relatywnie najmniejszy spadek natężenia fotosyntezy pod wpływem stresu suszy $(2 \mu \mathrm{mol}$ $\left.\mathrm{CO}_{2} \mathrm{~m}^{-2} \mathrm{~s}^{-1}\right)$, podczas gdy dla linii PW703, PW1027 i PW800 spadek natężenia fotosyntezy pod wpływem stresu suszy w stosunku do poziomu dla linii w warunkach optymalnych był większy i wynosił odpowiednio 20, 16 i $15 \mu \mathrm{mol} \mathrm{CO} \mathrm{Cm}^{-2} \mathrm{~s}^{-1}$ (Rys. 1). Linie PW1027, PW703 i CW738 charakteryzowały się najniższym poziomem fotosyntezy $\mathrm{w}$ warunkach suszy (odpowiednio 1,8; 4 i $5 \mu \mathrm{mol} \mathrm{CO}_{2} \mathrm{~m}^{-2} \mathrm{~s}^{-1}$ ).

Natężenie transpiracji było zróżnicowane zarówno dla linii wsobnych kapusty głowiastej białej w warunkach optymalnych jak i poddanych stresowi wodnemu (Rys. 2). Linią o najniższym natężeniu transpiracji $\mathrm{w}$ warunkach optymalnych była linia PW800 $\left(3,5 \mathrm{mmol} \mathrm{H}_{2} \mathrm{O} \mathrm{m}^{-2} \mathrm{~s}^{-1}\right)$, natomiast o najwyższym linia PW1265 (6,5 $\left.\mathrm{mol} \mathrm{H}_{2} \mathrm{O} \mathrm{m}^{-2} \mathrm{~s}^{-1}\right)$. W warunkach stresu wodnego linie PW903 i PW2517 nie wykazywały obniżenia poziomu transpiracji w porównaniu do warunków kontrolnych, podczas gdy dla linii PW703 i PW1018 obniżenie transpiracji w porównaniu do warunków kontrolnych wynosiło odpowiednio 4,6 i $3,7 \mathrm{mmol} \mathrm{H}_{2} \mathrm{O} \mathrm{m}^{-2} \mathrm{~s}^{-1}$. Linie PW1027, PW703 i CW738 wykazywały najniższy poziom transpiracji (odpowiednio 1,1, 1,4 i 1,7 mol $\left.\mathrm{H}_{2} \mathrm{O} \mathrm{m}^{-2} \mathrm{~s}^{-1}\right) \mathrm{w}$ warunkach stresu suszy. 


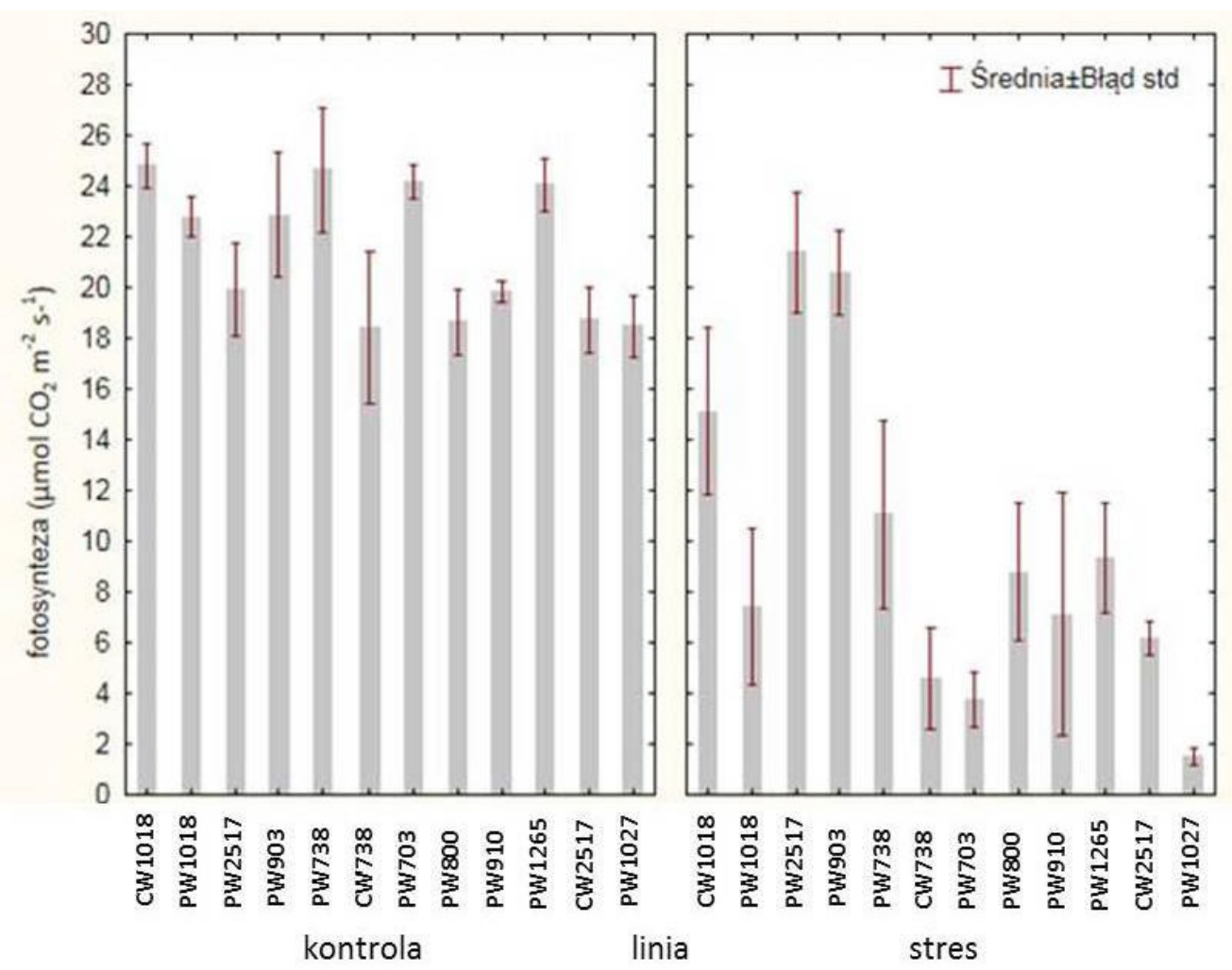

Rys. 1. Natężenie fotosyntezy ( $\left.\mu \mathrm{mol} \mathrm{CO}_{2} \mathrm{~m}^{-2} \mathrm{~s}^{-1}\right)$ dla 12 linii wsobnych kapusty głowiastej białej w warunkach optymalnych oraz stresu suszy.

Fig. 1. Intensity of photosynthesis ( $\left.\mu \mathrm{mol} \mathrm{CO} \mathrm{Cm}^{-2} \mathrm{~s}^{-1}\right)$ for 12 head cabbage inbred lines in optimal conditions under drought stress.

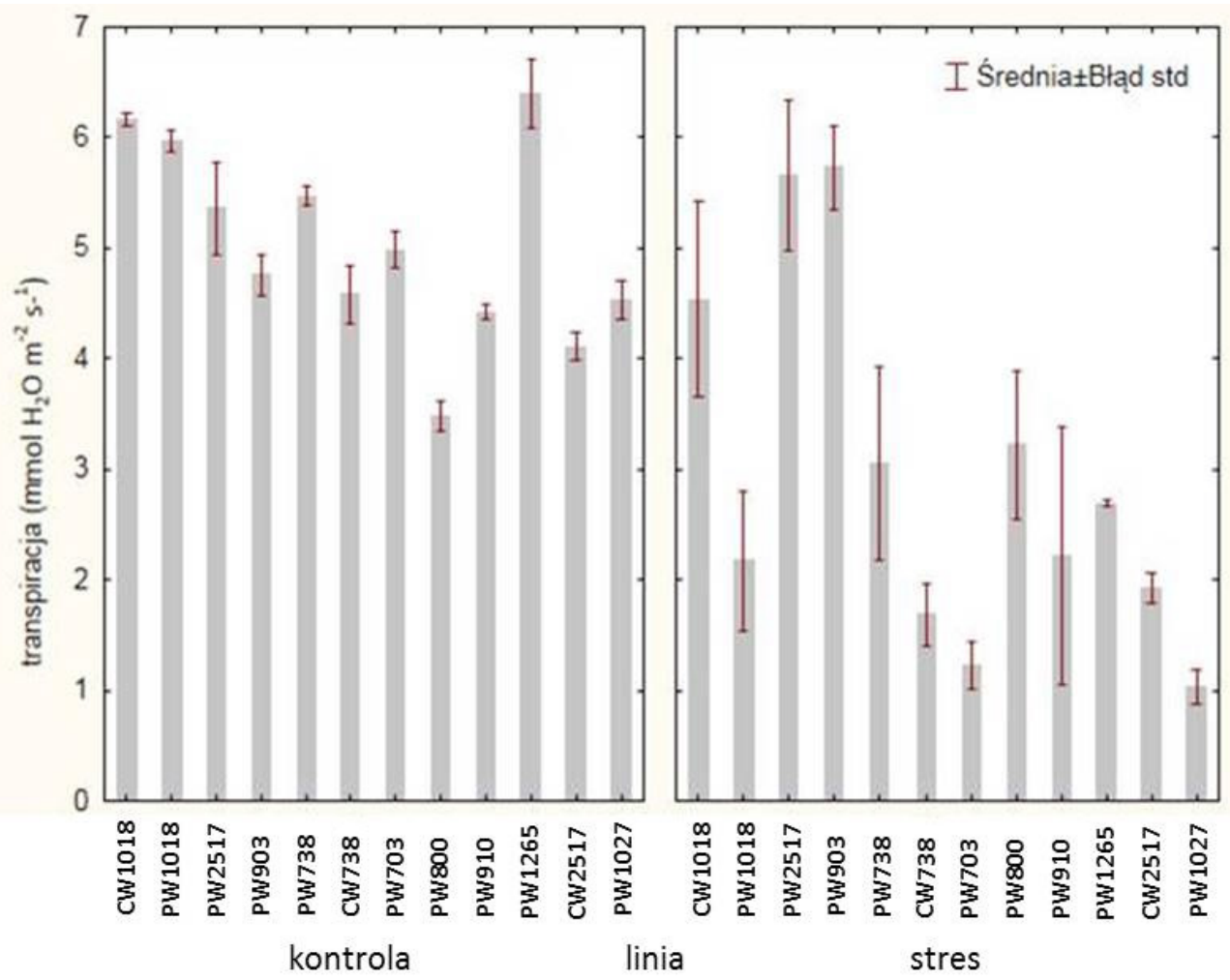

Rys. 2. Natężenie transpiracji (mmol $\left.\mathrm{H}_{2} \mathrm{O} \mathrm{m}^{-2} \mathrm{~s}^{-1}\right)$ dla 12 linii wsobnych kapusty glowiastej białej w warunkach optymalnych oraz stresu suszy

Fig. 2. Intensity of transpiration ( $\left.\mathrm{mmol} \mathrm{H}_{2} \mathrm{O} \mathrm{m}^{-2} \mathrm{~s}^{-1}\right)$ for 12 head cabbage inbred lines in optimal conditions under drought stress. 


\section{Ocena polowa}

Linie wsobne kapusty głowiastej białej w warunkach uprawy polowej charakteryzowały się bardzo dobrą jakością główek, wyrównaniem wewnątrzliniowym oraz zróżnicowanymi cechami morfologicznymi takimi jak masa główek, głąb wewnętrzny, wczesność, pokrój roślin, unerwienie liści, nalot woskowy i zwartość główki. Wszystkie linie wsobne posiadały kulisty lub kulisto-wydłużony kształt główek (Tabela 3).

Najwyższą masą główek odznaczała się linia PW1265 (3 kg), a najniższą linie PW1027 (1,48 kg) PW738 (1,50 kg). Najkrótszym głąbem wewnętrznym charakteryzowały się linie PW800 i PW1265 (stosunek długości głąba wewnętrznego do wysokości główki odpowiednio 0,26 i 0,29), a najdłuższym - linia PW903 (0,57). Oceniane linie odznaczały się długością wegetacji od 70 dla linii PW1027, PW1018 (Fot. 1H) do 130 dni od sadzenia na miejsce stałe dla linii PW2517 (Fot.1I). Linia (PW703) jako jedyna posiadała pokrój kompaktowy, natomiast pozostałe linie miały pokrój szeroki (PW1265, PW800, PW910) lub pośredni. Linia PW1265 odznaczała się słabszym unerwieniem liści w porównaniu do pozostałych linii o średnim lub silnym unerwieniu. Dwie linie (PW1265 i PW903) miały słabszy nalot woskowy w polu niż pozostałe genotypy o silnym woskowaniu liści. Linie PW1018 i CW 1018, które w fazie 16 liści właściwych w warunkach kontrolowanych odznaczały się słabym nalotem woskowym w warunkach polowych posiadały silny nalot woskowy. Wszystkie linie posiadały dobre i bardzo dobre wypełnienie główek z wyjątkiem linii PW903 i PW1265. Reakcja na stres suszy poszczególnych linii wsobnych kapusty głowiastej w warunkach polowych była stosunkowo niewielka, jednak pomiędzy poszczególnymi genotypami obserwowano różnice w intensywności więdnięcia liści zewnętrznych i okrywających główkę. Liniami reagujaccymi najsilniej były PW903 i PW1027, najsłabiej linia CW2517.

\begin{tabular}{|c|c|c|c|c|c|c|c|c|c|}
\hline & 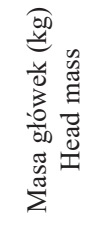 & 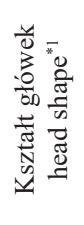 & 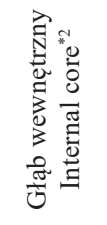 & 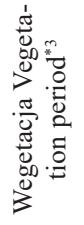 & 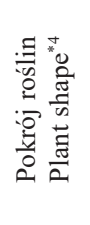 & 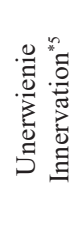 & 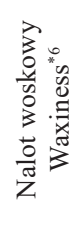 & 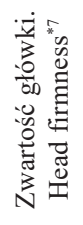 & 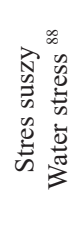 \\
\hline PW1265 & $3,00 \mathrm{e}$ & 1,01 & $0,29 \mathrm{~cd}$ & 75 & 3 & 1 & 2 & 8 & 9,0 \\
\hline PW2517 & $2,26 \mathrm{bd}$ & 1,06 & $0,53 \mathrm{ab}$ & 130 & 2 & 2 & 3 & 9 & 8,4 \\
\hline PW1018 & $1,74 \mathrm{ac}$ & 1,06 & $0,37 \mathrm{ad}$ & 70 & 2 & 3 & 3 & 9 & 9,0 \\
\hline PW738 & $1,50 \mathrm{a}$ & 1,07 & $0,48 \mathrm{ad}$ & 95 & 2 & 3 & 3 & 10 & 9,0 \\
\hline PW703 & $1,52 \mathrm{ac}$ & 1,07 & $0,44 \mathrm{ad}$ & 100 & 1 & 2 & 3 & 10 & 9,0 \\
\hline PW903 & $2,21 \mathrm{bd}$ & 1,02 & $0,57 \mathrm{a}$ & 120 & 2 & 2 & 2 & 7 & 8,3 \\
\hline PW800 & $1,77 \mathrm{ac}$ & 1,04 & $0,26 \mathrm{c}$ & 95 & 3 & 2 & 3 & 10 & 9,0 \\
\hline CW2517 & $2,36 \mathrm{~d}$ & 1,03 & $0,53 \mathrm{ab}$ & 130 & 2 & 2 & 3 & 9 & 9,7 \\
\hline PW910 & $2,11 \mathrm{bd}$ & 0,98 & $0,44 \mathrm{ad}$ & 110 & 3 & 3 & 3 & 9 & 8,0 \\
\hline PW1027 & $1,48 \mathrm{a}$ & 1,06 & $0,40 \mathrm{ad}$ & 70 & 2 & 2 & 3 & 9 & 8,3 \\
\hline CW1018 & $1,60 \mathrm{ac}$ & 1,07 & $0,38 \mathrm{ad}$ & 75 & 2 & 3 & 3 & 9 & 9,0 \\
\hline CW738 & $2,28 \mathrm{bd}$ & 1,04 & $0,55 \mathrm{ab}$ & 95 & 2 & 2 & 3 & 10 & 8,4 \\
\hline
\end{tabular}

* I - Stosunek wysokości do dtugości główki; head height/head width coefficient

*2 - Stosunek długości głąba wewnętrznego do wysokości główki; internal core/head height coefficient

*3 - Dlugość okresu wegetacji odsadzenia do osiagnięcia dojrzalości zbiorczej; vegetation from planting to harvest

*4-Pokrój roślin: 1-kompaktowy, 2-pośredni, 3-szeroki; Plant shape: 1-compact, 2 -intermediate, 3 -wide

*5 - Unerwienie: 1-stabe, 2-pośrednie, 3-silne; Innervation: 1 -weak, 2 -intermediate, 3 -strong

*6-Nalot woskowy: 1-staby, 2-średnii, 3-silny; Waxiness: 1 -weak, 2 -intermediate, 3 -strong

*7-Zwartość glówki: 10-zwarty, 1-luźny, Head firmness: 10-tight, 1-loose

*8 - Stres suszy: 0 - całkowite zaschnięcie, 10 - brak objawów; Water stress: 0 - total drought, 10 - lack of symptoms 


\section{Dyskusja}

Ocena linii wsobnych kapusty głowiastej białej jest częścią badań nad uzyskaniem komponentów rodzicielskich do tworzenia nowych odmian heterozyjnych odznaczających się większą odpornością na czynniki biotyczne i abiotyczne. Wykorzystanie zróżnicowanych genetycznie homozygotycznych linii wsobnych kapusty głowiastej pozwoliło na identyfikację cech morfologicznych, użytkowych i fizjologicznych oraz różnic pomiędzy liniami w reakcji na stres suszy, co może mieć wpływ na prowadzenie hodowli odpornościowej na stres suszy. Więdnięcie oraz ograniczenie wzrostu roślin kapusty głowiastej białej w wyniku stresu suszy były wcześniej obserwowane przez Kaniszewski i Rumpel 1998, Wiebe 1981. Uzyskane rezultaty potwierdziły, że selekcja wczesnych genotypów o wysokiej dynamice rozwoju systemu korzeniowego może pomóc w uzyskaniu odmian posiadających przewage w zdobywaniu wody i składników pokarmowych, co przekłada się na mniejszą podatność na stres wodny i w konsekwencji wyższy plon. Na uwage zasługują linie takie jak PW1027 i PW800, które odznaczały się najintensywniejszym przyrostem systemu korzeniowego i jednocześnie jego dużą dynamiką wzrostu. Szczególnie wczesna linia PW1027 (75 dni od sadzenia) może dzięki silnemu rozwojowi systemu korzeniowego uzyskać przewage $\mathrm{w}$ okresach niedoboru wody $\mathrm{w}$ polu i wytworzyć dobry plon. Dynamika wzrostu systemu korzeniowego w pierwszych etapach rozwoju może mieć mniejsze znaczenie dla późnych linii takich jak PW2517, CW2517 i PW903 niż dla linii wczesnych, gdyż dłuższy okres wegetacji (120-130 dni od sadzenia na miejsce stałe) daje większe możliwości kompensacji stresu suszy $\mathrm{w}$ trakcie późniejszego rozwoju roślin. Uzyskane wyniki pozwalają przypuszczać, że linie wsobne, które wytworzyły największą masę części nadziemnej w początkowym okresie wzrostu, jak PW903 mogą być bardziej podatne na stres suszy, ze względu na większą powierzchnię liści i silniejszą transpirację. Ograniczenie wymiany gazowej (fotosynteza i transpiracja) w warunkach stresu suszy dla linii wsobnych kapusty głowiastej są zgodne z obserwacjami autorów dla innych gatunków roślin (Chandler, Ferree 1990; Flore i in. 1985; Klamkowski, Treder 2006; Klamkowski i in., 2015). Stosunkowo wysoki poziom wymiany gazowej dla linii PW903 i PW2517 w warunkach niedoboru wody może mieć negatywny wpływ na jej odporność na stres wodny powodując wcześniejsze zasychanie i zamieranie roślin. Ograniczenie transpiracji i oddychania w warunkach stresu jest aktywnym mechanizmem zabezpieczającym rośliny przed więdnięciem (Leonardis i in. 2012). Z tego względu linie takie jak PW1027, PW703 i CW738, które ograniczały silnie te procesy $\mathrm{w}$ warunkach stresu mogą być wykorzystane w hodowli odpornościowej. Również linia PW738 o silnym unerwieniu i nalocie woskowym, gładkiej strukturze i ciemnej barwie liści może być w większym stopniu odporna na warunki stresu.

Przeprowadzona analiza pozwala lepiej zrozumieć mechanizmy związane $\mathrm{z}$ reakcją roślin kapusty głowiastej białej na stres wodny oraz przeprowadzić selekcję i rozmnożenie tych genotypów, które wykazują wyższy poziom odporności na suszę. Linie wsobne o kompaktowym pokroju, mniejszych liściach okrywających oraz wzniesionym lub pół-wzniesionym typie wzrostu mogą mieć większa przydatność w hodowli heterozyjnej, jeśli wykażą mniejszą podatność na stres suszy. Przeprowadzone badania pozwola w dalszych etapach na ocenę polową kolejnych pokoleń wsobnych linii kapusty głowiastej białej oraz na wytworzenie i ocenę eksperymentalnych mieszańców $F_{1}$ w oparciu o komponenty posiadające cechy związane z odpornością na stres wodny.

\section{Wnioski}

1. Użyte w badaniach linie wsobne kapusty głowiastej były zróżnicowane pod względem cech morfologicznych, użytkowych, wczesności, dynamiki wzrostu systemu korzeniowego oraz aktywności wymiany gazowej (fotosynteza i transpiracja) oraz pod względem reakcji na stres związany z niedoborem wody.

2. Wczesne genotypy o wysokiej dynamice rozwoju systemu korzeniowego mogą być mniej podatne na stres wodny.

3. Linie wsobne kapusty wytwarzające dużą masę części nadziemnej w początkowym okresie wzrostu mogą być bardziej podatne na stres suszy, ze względu na większą powierzchnię liści i silniejszą transpirację.

4. Wysoki poziom wymiany gazowej w warunkach niedoboru wody może mieć negatywny wpływ na odporność linii wsobnych kapusty na stres wodny powodując wcześniejsze zasychanie i zamieranie roślin.

5. Linie wsobne charakteryzujące się dużą dynamiką rozwoju systemu korzeniowego, mniejszymi liśćmi, kompaktowym pokrojem roślin, które odznaczały się także silniejszym ograniczeniem wymiany gazowej $\mathrm{w}$ warunkach suszy mogą być wykorzystane w hodowli odpornościowej na stres niedoboru wody. 
Badania wykonano $w$ ramach Zadań Celowych MRiRW Zadanie 2. Otrzymywanie materiatów hodowlanych kapusty głowiastej białej o podwyższonym poziomie odporności na stres suszy w warunkach polowych, z cecha cytoplazmatycznej meskiej sterylności oraz wyższa tolerancja na bakteryjne gnicie. Opracowanie efektywnej metody rozmnażania linii i mieszańców z cecha CMS.

\section{Literatura}

Ashraf M., Ozturk M., Athar H. R. Eds.(2009). Salinity and Water Stress. Improving Crop Efficiency. Task for Vegetation Science - 44 Springer Science +Buisness Media B.V., 1-228.

Bahadur Anant, Chatterjee Antra, Kumar Rajesh, Singh Major and Naik PS (2011). Physiological and biochemical basis of drought tolerance in vegetables. Vegetable Science 38 (1): $1-16$.

Blum A. (1988). Plant Breeding for Stress Environments. CRC Press. Plant breeding for stress environments. Boca Raton. CRC Press Inc. 223p.

Boyer J. S. (1970). Leaf enlargement and metabolic rates in corn, soybean, and sunflower at various leaf water potentials. Plant Physiol., 46, s. 233-235.

Chandler, C. K., Ferree, D. C. (1990). Response of 'Raritan' and 'Surecrop' strawberry plants to drought stress. Fruit Var. J., 44, 183-185.

Chaves, M. M., Maroco, J. P., Pereira, J. S. (2003). Understanding plant responses to drought - from genes to the whole plant. Funct. Plant Biol., 30, 239-264.

Dickson G. R. (2007). Vegetable Brassica and Related Crucifers. Crop Production Science in Horticulture 14. CAB International ed. 1-307.

Flore, J. A., Lakso, A. N., Moon, J. W. (1985). The effect of water stress and vapor pressure gradient on stomatal conductance, water use efficiency, and photosynthesis of fruit crops. Acta Hort., 171, 207-218.
Giuseppe M. B. Dichio (eds.). (2012). InTech Publisher. 45-74 pp. Breeding for drought tolerance in vegetables. Rajesh Kumar, Shashank Shekhar Solankey and Major Singh Vegetable Science 39 (1): 1-15.

Kaniszewski S., Rumpel J. (1998). Effect of irrigation, nitrogen fertilisation and soil type on yield and quality of cauliflower. Journal of Vegetable Crop Production4, 67-75.

Klamkowski, K., Treder, W. (2006). Morphological and physiological responses of strawberry plants to water stress. Agric. Conspec. Sci., 71, 159-165.

Klamkowski K., Treder W., Orlikowska T. (2015). Wpływ długotrwałego deficytu wody w podłożu na wybrane parametry fizjologiczne roślin trzech odmian maliny. Infrastruktura i Ekologia Terenów Wiejskich. Nr II/1/2015 603-611.

Leonardis A. M. D., Petrarulo M., Vita P. D., Mastrangelo A. M. (2012). Genetic and molecular aspects of plant response to drought in annual crop species. In: Advances in Selected Plant Physiology Aspects. InTech Publisher, Rijeka, 45-74.

Pavlović I., Mlinarić S., Tarkowská D., Oklestkova J., Novák O., Lepeduš H., Bok V. Brkanac S., Strnad M., Salopek-Sondi B. (2019). Early Brassica Crops Responses to Salinity Stress: AComparative Analysis Between Chinese Cabbage, White Cabbage, and Kale. Frontiers in Plant Science. SN - 1664-462X. https://www.frontiersin.org/article/10.3389/fpls.2019.0045010.3389/fpls.2019.00450.

Singer, S. M., Helmy, Y. I., Karas, A. N., Abou-Hadid, A. F. (2003). Influences of different water-stress treatments on growth, development and production of snap bean (Phaseolus vulgaris L.). Acta Hort., 614, 605-611.

Smittle D. A., 1994. Irrigation regimes affect cabbage water use and yield. Journal of the American Society for Horticultural Science 119, 20-23.

Wiebe H. J. (1981). Influence of soil water potential during different growth periods on yield of cauliflower. Acta Horticulturae 119, 299-300. 

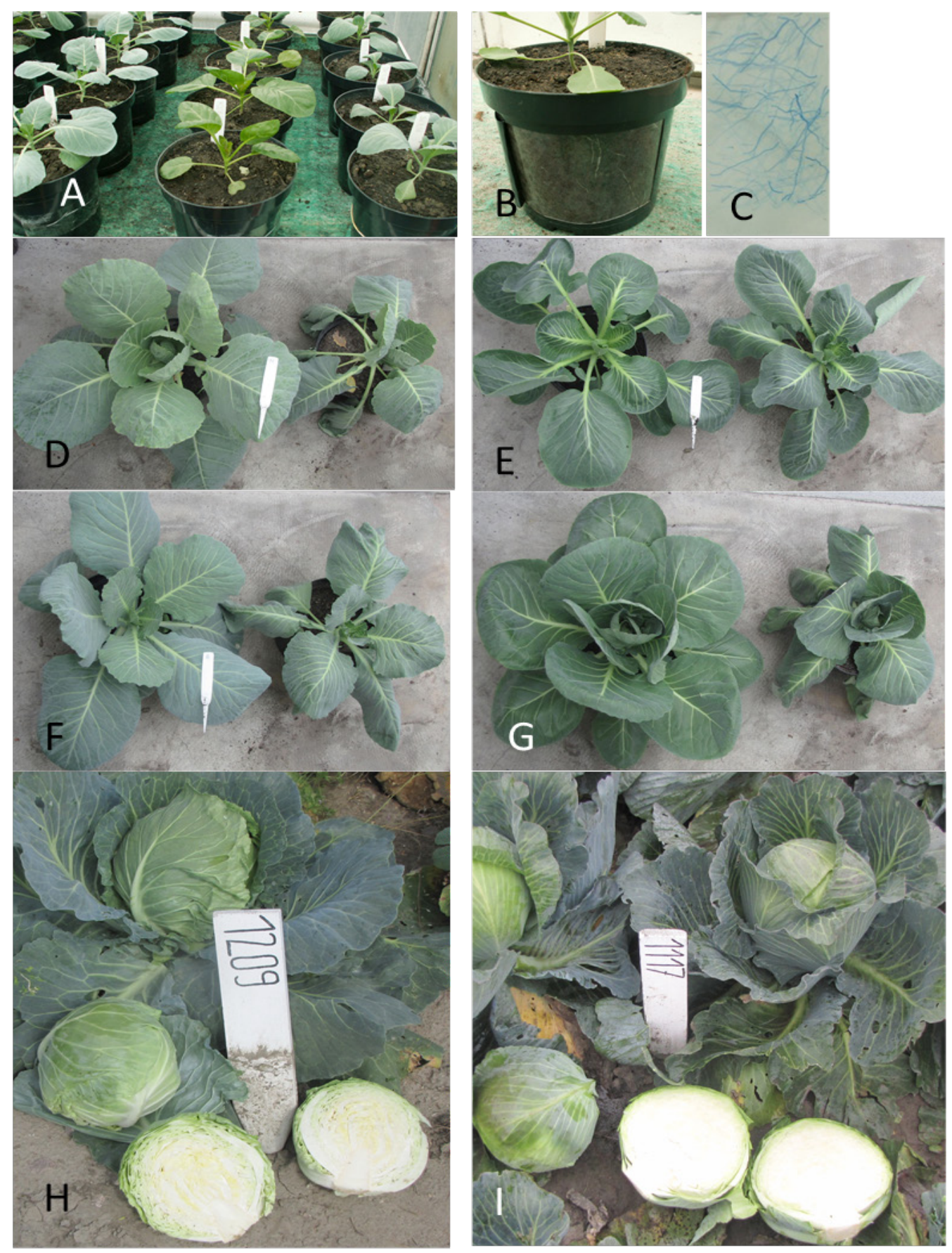

Fot. 1A - Zróżnicowanie morfologiczne oraz reakcja na stres suszy u badanych linii wsobnych kapusty glowiastej białej. 1A. rośliny w fazie 8 liści właściwych od lewej linia PW738, PW1018, PW2517; 1B, 1C - ramka odczytu dynamiki wzrostu systemu korzeniowego i odwzorowanie korzeni (I termin pomiaru); 1D, 1E, 1F, 1G - reakcja na stres suszy linii wsobnych PW703, CW2517, CW1018, PW903 (od lewej rośliny kontrolne, od prawej po stresie suszy w warunkach kontrolowanych); 1H, 1I - od lewej linia PW1018 i CW2517 w fazie dojrzałości zbiorczej (w warunkach polowych).

Fot.1A - Morphological differences of head cabbage inbred lines at 8 leaves stage: from the left PW738, PW1018, PW2517 lines; Fot. 1B, 1C reading frame for root growth observation; Fot. 1D, 1E, 1F, 1G - comparison of the drought stress for PW703, CW2517, CW1018, PW903 inbred lines (from the left: control plants, from the right: plants after drought stress); Fot. 1H, 1I - head cabbage CW1018 (left) and CW2517 lines at harvest stage. 